\title{
Effects of nutrient supplies on the growth rates of planktonic bacteria in Uchiumi Bay, Japan
}

\author{
Daisuke Ichinotsuka ${ }^{1}$, Toshiya Katano ${ }^{2,3}$, Hidetaka Takeoka ${ }^{2}$, Shin-ichi Nakano ${ }^{1,4, *}$ \\ ${ }^{1}$ LAFWEDY, Ehime University, Tarumi 3-5-7, Matsuyama 790-8566, Ehime, Japan \\ ${ }^{2}$ Center for Marine Environmental Studies, Ehime University, Bunkyo-cho 3, Matsuyama 790-8577, Japan \\ ${ }^{3}$ Ariake Sea Research Project, Saga University, 1 Honjo-cho, Saga 840-8502, Japan \\ ${ }^{4}$ Center for Ecological Research, Kyoto University, Hirano-cho 2 chome, 509-3, Otsu, Shiga 520-2113, Japan
}

\begin{abstract}
In the oligo- to mesotrophic waters of Uchiumi Bay, Japan, there is an intermittent physical event which supplies nutrients to the sea: bottom intrusion of deep, cool, nutrient-rich water that slides through just above the continental shelf. To determine the effects of nutrients supplied by this bottom intrusion on bacterial growth, we monitored seasonal changes in bacterial growth rates and conducted nutrient amendment experiments with single or mixed-nutrient additions of $\mathrm{N}$ and $\mathrm{P}$. In addition, we examined the importance of organic matter supply for bacterial growth rates using glucose. Bacterioplankton bulk growth rates ranged between 0.37 and $1.86 \mathrm{~d}^{-1}$, with relatively high growth rates during the period of strong thermal stratification. Neither positive nor negative effects on bacterial growth rates were detected by amendments of nutrients or glucose. A significant positive relationship ( $p<0.001)$ between cell density and production of bacteria was found, though the regression slope of bacterial cell density on bacterial production was relatively low (0.34). Our results suggested that bacterial growth rates in Uchiumi Bay are nearly saturated at ambient levels of nutrients and/or organic matter, and that bacterial abundance is subject to relatively weak bottom-up control.
\end{abstract}

KEY WORDS: Bacterial growth rate $\cdot$ Nutrient limitation $\cdot$ Bottom-up control

\section{INTRODUCTION}

Planktonic heterotrophic bacteria constitute a large portion of the planktonic biomass in both marine and freshwater ecosystems (Cho \& Azam 1990, Geller et al. 1991, Simon et al. 1992, Kawabata \& Nakanishi 1996). Thus bacterial utilization of inorganic and organic matter and the resultant production of bacterial biomass may account for a substantial part of material cycling in an aquatic system. Bacterial production depends on bacterial abundance, cell size and growth rate. It has been considered that abundance and growth rates of bacteria in natural aquatic environments are susceptible to subtle changes in environmental conditions (Hall et al. 2008). Studies on the seasonal dynamics of bacterial abundance frequently show a relative constancy of cell density over time (Azam et al. 1983, Pace 1988). In contrast, bacterial growth rates vary depend- ing on environmental variables: temperature, nutrient and energy supplies as bottom-up controls, and grazing and viral lysis as top-down controls (Church et al. 2000, Sala et al. 2002). Bacterial growth rates are therefore a useful measure in elucidating environmental factors which may cause changes in bacterial production. There is a significant correlation between bacterial growth rates and phytoplankton biomass (Cole et al. 1988, White et al. 1991). Thus it is well accepted that bacterial growth rates are closely related to the productivity of an aquatic ecosystem.

Owing to their bulk in nucleic acids and proteins, the $\mathrm{N}$ and $\mathrm{P}$ requirements of bacteria are large. This necessitates that bacterial cells maintain low intracellular C:N:P ratios (Tezuka 1990, Goldman et al. 1991). The amount of available nutrients can therefore constrain bacterial growth rates (Rivkin \& Anderson 1997, Caron et al. 2000, Hoch \& Bronk 2007). Evidence has been ac- 
cumulated that bacteria in the Atlantic Ocean, the Mediterranean Sea and the Baltic Sea are limited by inorganic nutrients, mainly P (Rivkin \& Anderson 1997 , Caron et al. 2000, Pinhassi et al. 2006). Also, nutrient limitation of bacterial growth in lakes has been intensively studied (Morris \& Lewis 1992, Elser et al. 1995, Jansson et al. 1996). However, such information is relatively limited for marine coastal waters, especially in the western Pacific Ocean.

The Uwa Sea is located along the southwestern coast of Shikoku Island, Japan. The trophic state of the sea has been considered meso- to oligotrophic (Tomaru et al. 2002). Within this system, there is an intermittent physical event which supplies nutrients to the sea: the bottom intrusion of deep, cool, nutrient-rich Pacific water which slides just above the continental shelf (Kaneda et al. 2002a,b). Large amounts of nitrate and phosphate supplied by bottom intrusion are the major nutrient source for phytoplankton primary production in the sea (Koizumi 1991, Koizumi \& Kohno 1994, Koizumi et al. 1997, Takeoka et al. 2000). Since inorganic N (Rivkin \& Anderson 1997) and/or P (Rivkin \& Anderson 1997, Caron et al. 2000, Pinhassi et al. 2006) supply stimulate bacterial growth in marine environments, bottom intrusion may also serve as an important supply of nutrients for bacteria in the Uwa Sea. The importance of nutrients supplied through bottom intrusion on bacterial growth rates remains to be resolved.

In the present study, to elucidate the effects of nutrient supplies by bottom intrusion on bacterial growth rates, we monitored seasonal changes in bacterial growth rates and conducted nutrient amendment experiments in a bay of the Uwa Sea. To identify which nutrient is important for accelerating bacterial growth rates, we performed single or mixed-nutrient addition experiments. We also examined the importance of organic matter supply for bacterial growth rates. input to the coastal areas (Koizumi 1991, Koizumi \& Kohno 1994, Koizumi et al. 1997, Takeoka et al. 2000). While the effect of Kyucho on phytoplankton growth is negligible, diatom blooms have been observed to be promoted by nutrient inputs by bottom intrusion (Koizumi \& Kohno 1994, Koizumi et al. 1997). Thus the trophic status of the Uwa Sea is temporarily changed when a bottom intrusion happens, and the dominant biological matter cycling may be changed by a shift in the dominant food linkages from a microbial to an herbivorous food web (Nakano et al. 2004).

The present study was conducted at Stn Ub $\left(33^{\circ} 2^{\prime} \mathrm{N}\right.$, $132^{\circ} 28^{\prime} \mathrm{E}_{\text {; }}$ water depth ca. $53 \mathrm{~m}$; Fig. 1) in Uchiumi Bay, located in Iegushi, Uchiumi Village, Ehime Prefecture, Japan (Nakano et al. 2004), which opens to the Bungo Channel within the Uwa Sea (Fig. 1). The channel is strongly affected by an oligotrophic Kuroshio front (Takeoka et al. 2000). There are no rivers or streams flowing into the bay, so there is negligible effect on water quality by nutrient loading of inflows. Stn Ub was located in the center of a pearl oyster culture farm. Water samples were collected monthly using a 61 Van-Dorn water sampler from 0, 2, 5, 10, 15, 20, 30, 40 and $50 \mathrm{~m}$ depths from June 2002 to June 2003. The vertical distribution of water temperature was determined with a Chlorotech profiler (Arec Electronics, ACL-208-DK). To monitor the occurrence of bottom intrusion, the water temperature was measured every $30 \mathrm{~min}$ with a thermistor chain at 2 and $60 \mathrm{~m}$ depths at Stn Ut (Fig. 1).

A $100 \mathrm{ml}$ portion of the water sample was filtered through a $0.2 \mu \mathrm{m}$ Nuclepore filter, and the filtrate was used for measuring the concentration of dissolved inorganic $\mathrm{N}$ (DIN, $\mathrm{NO}_{3}^{-}+\mathrm{NO}_{2}^{-}+\mathrm{NH}_{4}^{+}$) and soluble reactive $\mathrm{P}$ (SRP) using an AutoAnalyzer 3 (Bran-Luebbe).

Another $100 \mathrm{ml}$ portion of the water sample was filtered through a GF/F filter (Whatman) precombusted

\section{MATERIALS AND METHODS}

Monthly monitoring of physicochemical and biological parameters. There are 2 major physical events in the Uwa Sea: Kyucho and bottom intrusion, both of which occur mainly in summer. Kyucho is an intrusion of warm, oligotrophic surface water from the south of the Bungo Channel to the west coast of Shikoku Island (Takeoka \& Yoshimura 1988, Takeoka et al. 1993). Bottom intrusion consists of deep, cold, nutrient-rich water that flows just over the continental shelf (Takeoka et al. 2000, Kaneda et al. 2002a,b), serving as the major nutrient

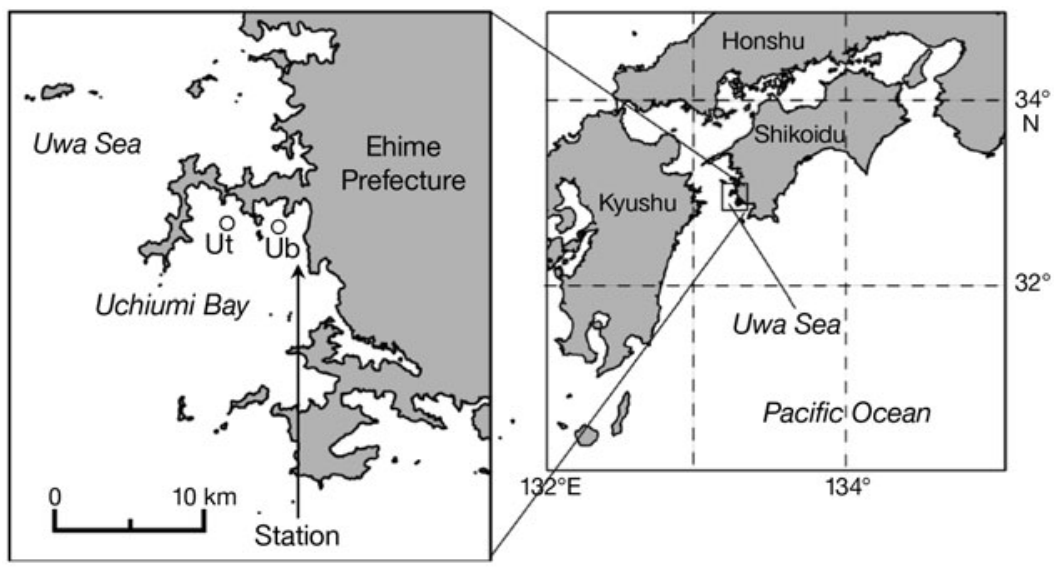

Fig. 1. Locations of the sampling station (Stn Ub) and temperature monitoring station (Stn Ut) in Uchiumi Bay, Japan 
at $45^{\circ} \mathrm{C}$ for $2 \mathrm{~h}$, and the filtrate was used to measure the concentration of dissolved organic $C$ (DOC) using a total $\mathrm{C}$ analyzer (TOC-V, Shimadzu). DOC measurements were conducted between February 2003 and August 2003.

To determine chlorophyll a (chl a) concentration, a $100 \mathrm{ml}$ water sample was filtered through a $0.2 \mu \mathrm{m}$ Nuclepore filter to retain seston. Each filter retaining seston was put into a glass test tube, and $6.5 \mathrm{ml}$ of $\mathrm{N}$, $\mathrm{N}$-dimethylformamide (DMF) was added to extract chl a. The amount of chl a thus extracted was determined using the fluorometric method (Moran \& Porath 1980).

For enumeration of heterotrophic bacteria, a water sample $(100 \mathrm{ml})$ was fixed with glutaraldehyde at a final concentration of $1 \%$. Bacteria were stained with 4'6-diamidino-2-phenylindole (DAPI) and filtered on black polycarbonate filters $(0.2 \mu \mathrm{m}$ pore size, Porter \& Feig 1980). At least 300 bacterial cells, in most cases $>400$ cells, on the filter were counted using an epifluorescence microscope under UV excitation.

Nutrient amendment experiment. We used the dilution method for determining nutrient limitation on bacterial growth rates. The method proposed by Kirchman et al. (1982) and used for studies on nutrient limitation on bacterial growth in various environments (Morris \& Lewis 1992, Felip et al. 1996, Rivkin \& Anderson 1997, Middelboe et al. 2002) was followed. Water samples were collected from $10 \mathrm{~m}$ depth, where high abundances of phytoplankton and bacteria have been previously observed (Katano et al. 2004, 2005, Ichinotsuka et al. 2006). The sample was subjected to size-fractionations as follows: $0.8 \mu \mathrm{m}$ Nuclepore filter for removing consumers of bacteria such as protists under negative pressure at $0.05 \mathrm{MPa}$, and $0.2 \mu \mathrm{m}$ Gelman culture capsule filter for removing all planktonic organisms using gravity. We discarded the first $1 \mathrm{l}$ of the Gelman culture capsule filtrate to minimize the contamination of dissolved organic matter released from the filter. We diluted the $<0.8 \mu \mathrm{m}$ filtrate into the $<0.2 \mu \mathrm{m}$ filtrate at a dilution level of 0.1 , and $200 \mathrm{ml}$ portions of the diluted water sample were poured into twenty $250 \mathrm{ml}$ polycarbonate bottles. Based on microscopic observation, cell size of heterotrophic nanoflagellates was mostly 4 to 5 $\mu \mathrm{m}$. Thus our manipulation removed most protist cells from the seawater. Moreover, the removal of grazers and the dilution of the sample resulted in a reduction in the amount of grazing on bacteria. $\mathrm{NH}_{4} \mathrm{Cl}\left(\mathrm{NH}_{4}\right)$ as inorganic $\mathrm{N}, \mathrm{NaH}_{2} \mathrm{PO}_{4}\left(\mathrm{PO}_{4}\right)$ as inorganic $\mathrm{P}$ and glucose as organic matter were added to each of 4 bottles

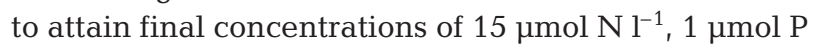

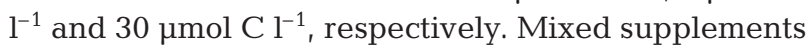
were also made. Thus our experiment was carried out in 4 replications. The remaining 4 bottles served as the control. The 20 bottles thus prepared were incubated at $10 \mathrm{~m}$ depth in the nearshore waters of Uchiumi Bay for $24 \mathrm{~h}$. A recent study on bacterial production in a marine environment showed that, although the incubation duration of $1 \mathrm{~d}$ was enough to detect changes in bacterial production using the leucine uptake method, changes in bacterial abundance could not be discerned (Pinhassi et al. 2006). However, we also conducted the experiments using $48 \mathrm{~h}$ incubation to determine bacterial growth rate between June 2002 and February 2003, and found that the bacterial growth rates derived from $24 \mathrm{~h}$ incubation were not significantly different from those of $48 \mathrm{~h}$ incubation (data not shown). Therefore, we decided to use bacterial growth rates determined in experiments of $24 \mathrm{~h}$ incubation. At time zero and at the end of the incubation, subsamples for the enumeration of bacteria were taken and fixed as mentioned above. The growth rate, $\mu\left(\mathrm{d}^{-1}\right)$ was calculated from the equation $\mu=\ln \left(N_{\mathrm{f}} / N_{0}\right) / t$, where $N_{0}$ and $N_{\mathrm{f}}$ are cell densities (cells $\mathrm{ml}^{-1}$ ) at time zero and after $1 \mathrm{~d}$ of incubation, respectively, and $t$ is the incubation period (d). One-way ANOVA was used to test for differences among treatments; subsequent multiple comparisons were performed using Tukey's test with a statistical significance level of $\mathrm{p}<0.05$.

Estimation of bacterial production. Bacterial production, $B P\left(\mu \mathrm{g} \mathrm{C} \mathrm{l}^{-1} \mathrm{~d}^{-1}\right)$, was calculated as follows:

$$
B P=N\left(\mathrm{e}^{\mu_{\mathrm{c}}}-1\right) \times V \times F
$$

where $N$ is the bacterial count (cells ml ${ }^{-1}$ ), $\mu_{\mathrm{c}}$ is mean bacterial growth rate in the control bottles, $V$ is the bacterial cell volume of $0.146 \mu^{3}$ (Nagata \& Watanabe

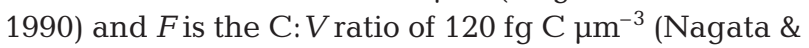
Watanabe 1990).

\section{RESULTS}

From June to October 2002, we detected 11 occurrences of bottom intrusion (Fig. 2). Among our sampling dates, 2 July, 2 August and 9 October 2002 were during the occurrence of bottom intrusion (Fig. 2, Table 1). Our CTD monitoring data revealed that bottom intrusion also occurred on 18 June 2003 (data not shown). From late August to mid September, water temperature at $2 \mathrm{~m}$ depth increased from 23.8 to $27.6^{\circ} \mathrm{C}$, indicating the occurrence of Kyucho, intrusion of warm, oligotrophic surface water from the south of the Bungo Channel to the west coast of Shikoku Island (Takeoka \& Yoshimura 1988, Takeoka et al. 1993). In Uchiumi Bay, thermal stratification usually develops between May and September (Katano et al. 2004, 2005, Ichinotsuka et al. 2006). This was also the case during the sampling period for the present study, though thermal stratification in May 2003 was still minor (Fig. 3). Thus we can divide the study period into 


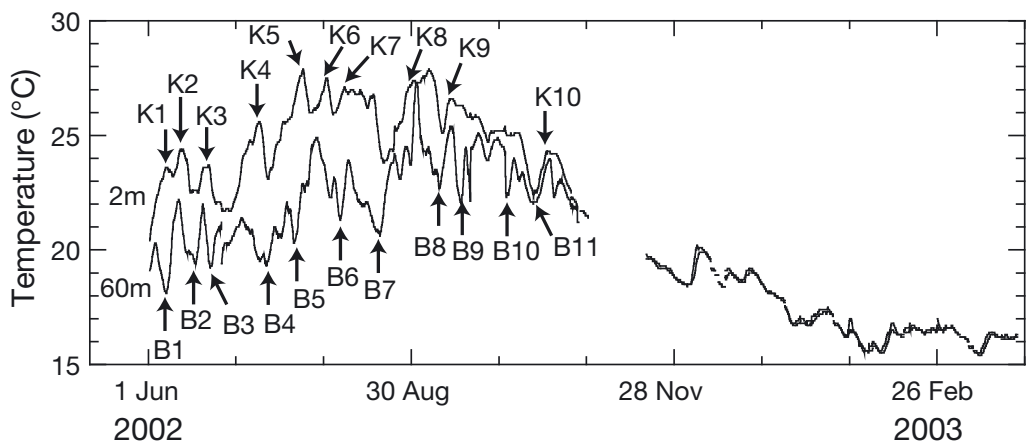

Fig. 2. Changes in water temperature at 2 and $60 \mathrm{~m}$ depths at Stn Ut (see Fig. 1). B1-B11: bottom intrusion events; K1-K10: Kyucho events. Breaks in the lines are due to lack of data

Table 1. Sampling dates and the days after the bottom intrusion. See Fig. 2 for bottom intrusion events. -: bottom intrusion was not detected before the sampling date; nd: not determined due to lack of data

\begin{tabular}{|lcc|}
\hline Date & $\begin{array}{c}\text { Days after } \\
\text { bottom intrusion }\end{array}$ & Event no. \\
\hline 13 Jun 02 & - & B4 \\
12 Jul 02 & 1 & B6 \\
2 Aug 02 & 0 & B11 \\
11 Sep 02 & - & \\
9 Oct 02 & 0 & \\
8 Nov 02 & nd & \\
10 Dec 02 & - & \\
17 Jan 03 & - & \\
13 Feb 03 12 Mar 03 & - & \\
16 Apr 03 & - & \\
20 May 03 & nd & \\
18 Jun 03 & nd \\
a Identified with unpublished data collected by the Ehime \\
Prefectural Fishermen's Cooperative Association \\
\hline
\end{tabular}

stratified (from May to September) and well-mixed (from October to March) periods.

Seasonally changing patterns were found in concentrations of DIN and DIP (Fig. 3b,c). High concentrations of these nutrients were detected at $20-50 \mathrm{~m}$ depth in July, August and October when bottom intrusion occurred (Figs. 2 \& 3b,c). In October 2002, nutrient concentrations throughout the water column were high: 2.44 to $6.67 \mu \mathrm{mol} \mathrm{N} \mathrm{^{-1 }}$ (Fig. 3a), and 0.27 to

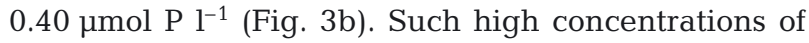
DIN and DIP continued during the mixing period from October to March. In September 2002, concentrations of these nutrients were low throughout the water column, due to the intrusion of Kyucho (Fig. 2).

A high concentration of DOC was detected in February 2003 at $0-15 \mathrm{~m}$ depth $\left(176.7 \mu \mathrm{mol} \mathrm{C} \mathrm{l}^{-1}\right)$, and it decreased to $50.4 \mu \mathrm{mol} \mathrm{C} \mathrm{l}^{-1}$ in April (Fig. 3d). The information about DOC concentration in the present study is limited. However, we continued to determine DOC concentration in 2003, 2004 and 2005 and observed no seasonal change in the vertical profile of DOC concentrations (authors' unpubl. data).

Chl a concentrations ranged from 0.17 to $1.77 \mu \mathrm{g} \mathrm{l}^{-1}$ during the investigation (Fig. 3e). The concentrations from August to December 2002 did not show a clear vertical distribution, and cyclic changes between high and low concentrations occurred from month to month (Fig. 3e).

Bacterial cell counts ranged between $0.4 \times$ $10^{6}$ and $2.7 \times 10^{6}$ cells ml ${ }^{-1}$ (Fig. 3f). Higher bacterial numbers were detected throughout the water column from June to September 2002 and from April to June 2003 (Fig. 3f). The period of high bacterial density roughly corresponded to the stratified period (Fig. 3a,f); otherwise, the difference in bacterial density between 0-15 and 20-50 m depth was not clear.

Bacterial growth rates (control treatment) at $10 \mathrm{~m}$ depth in Uchiumi Bay ranged between 0.37 and $1.86 \mathrm{~d}^{-1}$ (Fig. 4) and showed a clear seasonal change with relatively high growth rates during the stratified period (Figs. 3a \& 4). In most cases, nutrients or glucose addition did not have an effect on bacterial growth rates, and a statistically significant stimulation of bacterial growth rates was only detected in the experiment with phosphate addition in January 2003 (Fig. 4).

There was no significant correlation between bacterial growth rate and any of the environmental variables (water temperature and concentrations of DIN, DIP and chl a) examined in the present study. The seasonally changing pattern of bacterial production was almost identical to that of bacterial growth rates (data not shown). We tried Billen's approach (Billen et al. 1990) to examine the relationship between cell density and production of bacteria, and found a significant logarithmic relationship $\left(\mathrm{r}^{2}=0.78, \mathrm{p}<0.001, \mathrm{n}=13\right.$, slope $=0.34 ;$ Fig. 5) .

\section{DISCUSSION}

Bacterial cell density is suggested to increase with the increase in bacterial production, implying that bacterial biomass at steady state is a direct function of substrate supply (Billen et al. 1990, Pace \& Cole 1994). Previous studies have used Billen et al. (1990) to examine bottom-up control of bacterial biomass from the regression slope of bacterial biomass versus bacterial production (Pace \& Cole 1994, Dufour \& Torreton 1996). Low slope values found in the open ocean (e.g. 0.28) (Dufour \& Torreton 1996) suggest that bottom-up 

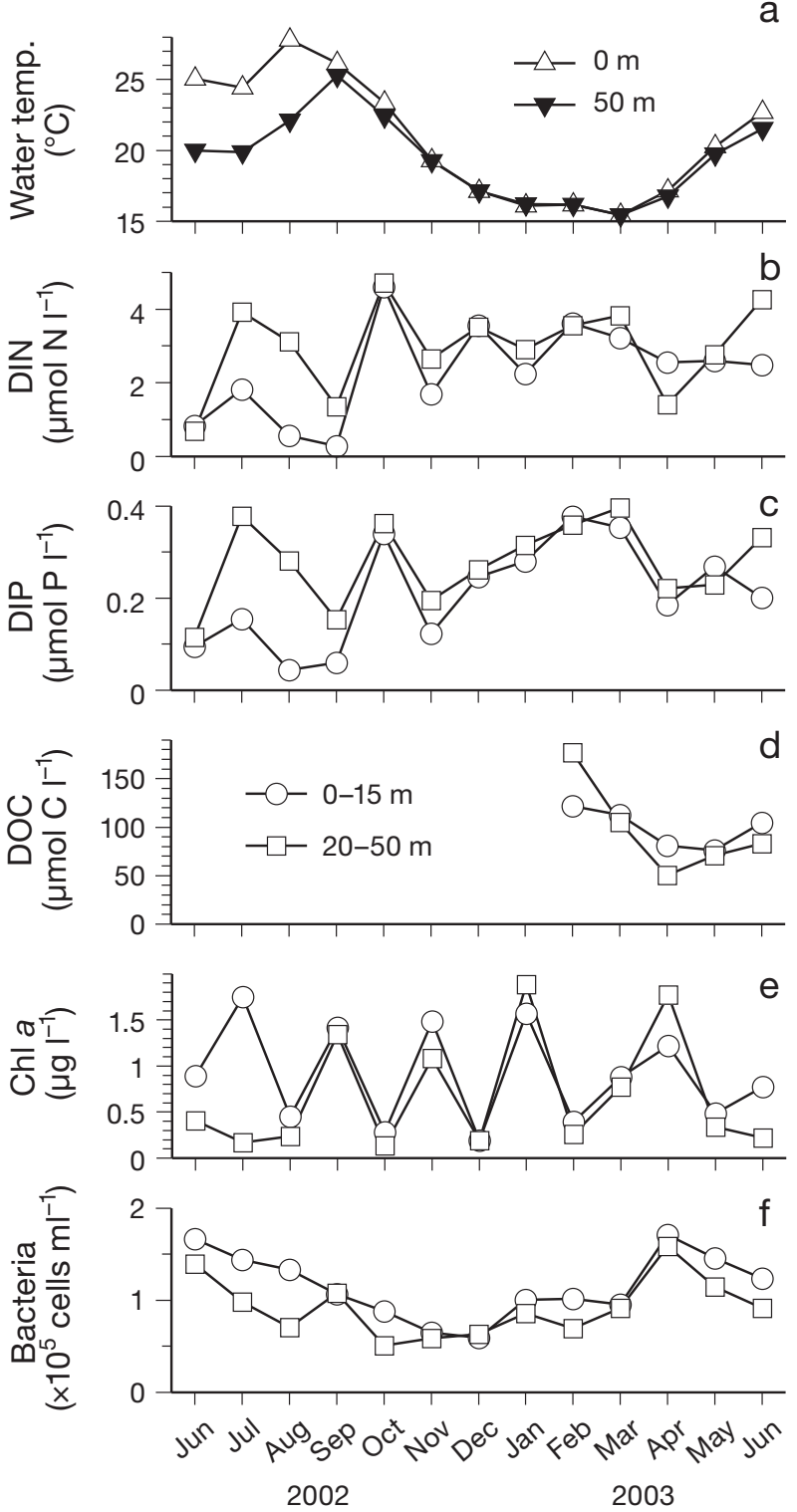

Fig. 3. Seasonal changes in (a) water temperature, (b) dissolved inorganic nitrogen (DIN) concentrations, (c) dissolved inorganic phosphorus (DIP) concentrations, (d) dissolved organic carbon (DOC) concentrations, (e) chl a concentrations and (f) bacterial cell densities. White and black triangles in (a) show data from 0 and $50 \mathrm{~m}$ depths, respectively, and white circles and squares in $(b-f)$ show mean values of samples collected from $0-15$ and 20-50 m depth, respectively

control on bacterial biomass is weak, while high slope values found in productive waters (e.g. 0.7, Billen et al. 1990) signify substantial bottom-up control on bacterial biomass. In the present study, the regression slope of bacterial cell density on bacterial production was 0.34, suggesting bottom-up control on bacterial abundance in Uchiumi Bay is weak relative to that of other waters (Billen et al. 1990, Pace \& Cole 1994). In our previous study (Ichinotsuka et al. 2006), turnover rates of bacteria due to grazing by nanoflagellates and ciliates ( 1 to $16 \% \mathrm{~d}^{-1}$ ) were seasonally high, indicating seasonal importance of top-down control on bacterial abundance. This may be why we detected weak bottom-up control on bacterial abundance in the bay.

Most bacterial production rates in previous studies have been determined by ${ }^{3} \mathrm{H}$-thymidine or ${ }^{14} \mathrm{C}$-leucine incorporation methods (Riemann et al. 2000, Choi et al. 2001, Lee et al. 2001, Vaqué et al. 2001). We used a bottle incubation method because radioactive tracers are restricted from use in natural environments in Japan. Since bacterial growth rates were within the range of bacterial growth rates of previous studies (Table 2), bacterial growth rates determined in Uchiumi Bay should be comparable to those in other environments.

Previous studies have demonstrated nutrient (Pomeroy \& Deibel 1986, Caron et al. 2000, Sala et al. 2002, Hoch \& Bronk 2007) and organic matter (Caron et al. 2000, Carlson et al. 2002, Sala et al. 2002, Flaten et al. 2003) limitation on growth of marine bacteria. Caron et al. (2000) reported that the supplement of glucose to a water sample from the eutrophic waters of Georges Bank stimulated bacterial growth, whereas bacterial growth in water samples from oligotrophic waters of the Sargasso Sea was enhanced by a supplement of inorganic $\mathrm{N}$ and $\mathrm{P}$. Bacterial growth rates from the present study in almost all cases were not stimulated by nutrient or glucose addition (Fig. 4), though the water was oligo- to mesotrophic. Hence our results suggest that bacterial growth rates in Uchiumi Bay are nearly saturated at ambient levels of nutrients and/or organic matter.

The bacterial growth saturation by inorganic nutrients and/or organic matter (Fig. 4) seems to contradict the bottom-up control of bacterial abundance (Fig. 5). One explanation for this is the perhaps inappropriate $\mathrm{C}$ source (glucose as a supply of organic matter) used in the experiment. Recent studies have demonstrated that not all marine bacteria use glucose (Malmstrom et al. 2005, Alonso \& Pernthaler 2006, Alonso-Saez \& Gasol 2007). In Uchiumi Bay, one of the dominant bacterial phylogenetic groups throughout the year is Cytophaga-Flavobacterium (authors' unpubl. data), and it has been reported that the bacteria included in the group show active uptake of glucose at high concentrations (Alonso \& Pernthaler 2006). Since glucose

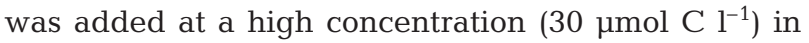
our nutrient amendment experiment, stimulation of bacterial growth rates would be expected. However, almost no response was found in bacterial growth rates (Fig. 4). Other organic substances, such as amino acids (Schweitzer \& Simon 1995), might be stimulative for bacterial growth in Uchiumi Bay, though we did not examine them in the present study. 


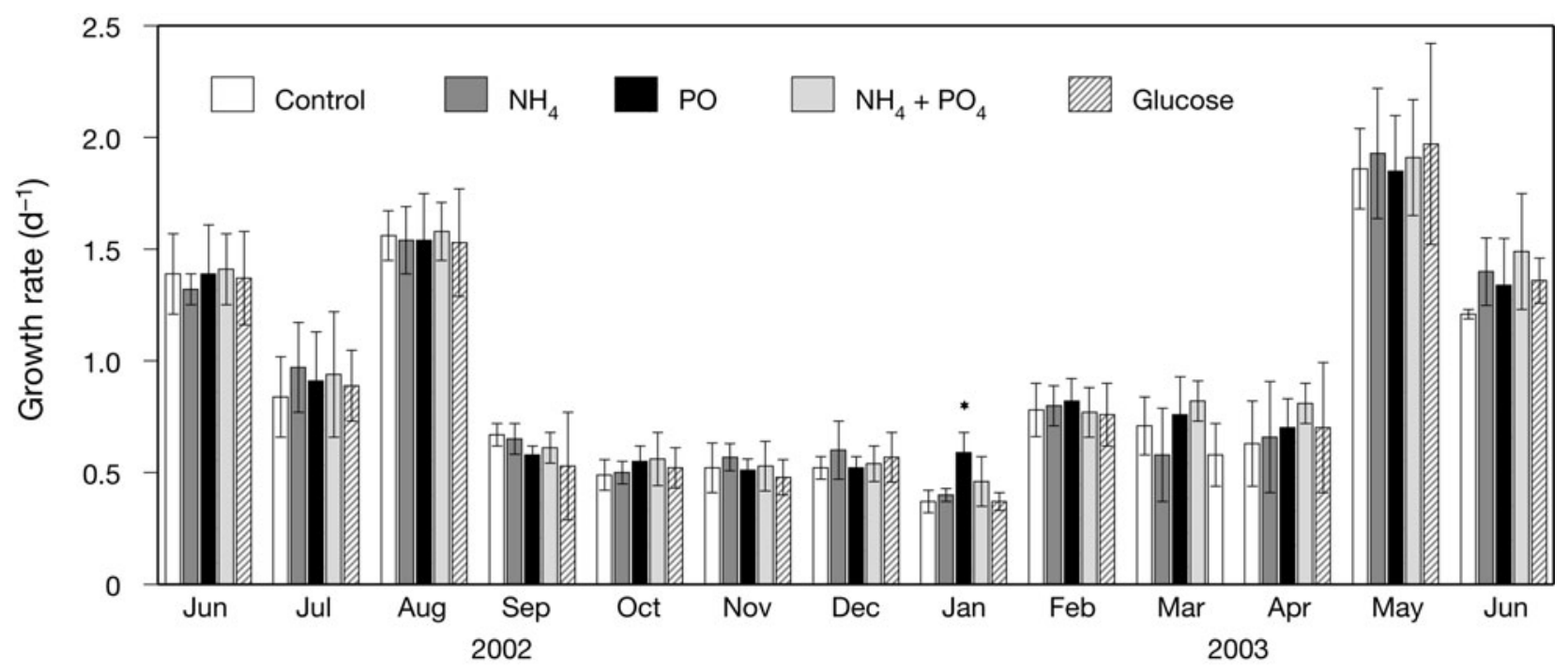

Fig. 4. Growth rate of bacteria obtained in the nutrient amendment experiments. Data are mean \pm SD for 4 replications. * significant difference (Tukey's test after 1-way ANOVA, p < 0.05) among the treatments in January

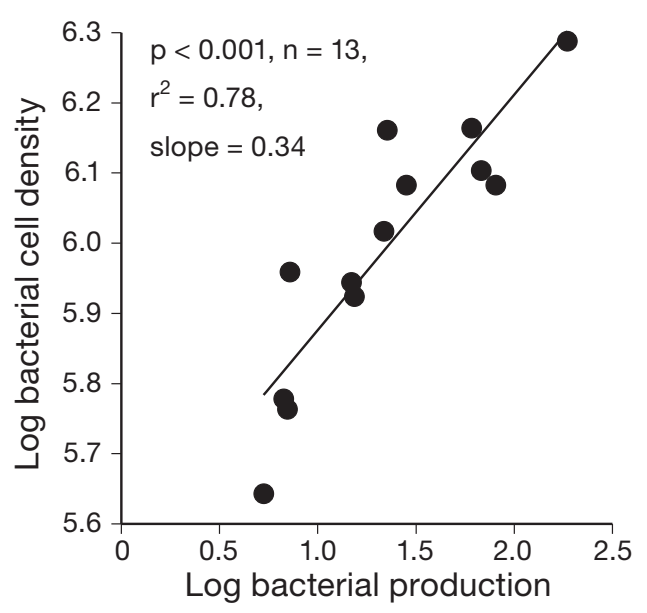

Fig. 5. Logarithmic relationship between bacterial cell density and bacterial production from June 2002 to June 2003 in Uchiumi Bay. Bacterial production was calculated from growth rate and cell density

Table 2. Growth rates of bacteria from the literature and the present study

\begin{tabular}{|lcl|}
\hline Location & Growth rate $\left(\mathrm{d}^{-1}\right)$ & Source \\
\hline Catalano-Balearic Basin, & $0.19-1.54$ & Sala et al. (2002) \\
$\quad$ Mediterranean Sea & $0.02-2.57$ & Lee et al. (2001) \\
Funka Bay & $0.01-0.35$ & Vaqué et al. (2001) \\
NW Mediterranean Sea & $0.01-0.31$ & Sherr et al. (2001) \\
Oregon Coast & $0.1-1.2$ & Hamels et al. (2001) \\
Schelde estuary & $0.3-2.2$ & Riemann et al. (2000) \\
Scripps Pier & $0.02-0.78$ & Church et al. (2000) \\
Southern Ocean & $0.16-1.46$ & Choi et al. (2001) \\
West of Barbados, Caribbean Sea & $0.37-1.86$ & Present study \\
Uchiumi Bay & & \\
\hline
\end{tabular}

Our monthly monitoring data from 2001 to 2005 at the station showed a significant positive relationship between bacterial cell density and chl a concentration ( $\mathrm{p}<0.05, \mathrm{n}=48$, data not shown). This supports the conclusion that bacterial abundance depends highly on primary production. Thus organic matters derived from exudates of phytoplankton possibly control bacterial growth rates.

The other explanation for the contradiction is temperature. In the present study, bacterial cell densities and bacterial growth rates tended to be high during the stratification period (Figs. $3 \& 4$ ), although the relationships were not significant. Our monthly monitoring data showed a similar trend: bacterial cell density was high during the warm water season, although a significant relationship was not detected (data not shown). Therefore, water temperature may be another possible factor in the control of bacterial abundance.

Cross-system analyses using data from various marine and freshwater ecosystems showed that bacterial abundance had a positive correlation with chl a concentration (Bird \& Kalff 1984, Cole et al. 1988, Sommaruga \& Robarts 1997). These findings suggest that bacterial abundance was mainly supported by DOC derived from phytoplankton. However, seasonal changes in the vertical bacterial density of the present study (Fig. 3B) were different from those of chl a (Fig. 3A) and DOC concentrations, and we did not find any significant relationship between bacterial growth rate and chl a concentration. These results suggest that DOC supply 
by phytoplankton was of minor importance for bacterial density in Uchiumi Bay.

A previous study by Hashimoto \& Nakano (2003) indicated that phytoplankton in Uchiumi Bay was subjected to systemic and/or growth rate limitations by $\mathrm{N}$, $\mathrm{P}$ or $\mathrm{Si}$. Hence we expected that bacterial growth rates would have been stimulated by the addition of nutrients or organic matter; however, this was not the case (Fig. 4). In Uchiumi Bay, differences in the response to nutrient supply between large and small phytoplankton have been reported (Nakano et al. 2004). Major nutrient supply to the bay is primarily due to bottom intrusion (Takeoka et al. 2000), and the high abundance of larger phytoplankton such as diatoms is detected when nutrients are supplied by bottom intrusion (Nakano et al. 2004). In contrast, the abundance of small phytoplankton such as picophytoplankton is high during periods of warmer water temperature, independent of nutrient supply, due to the occurrence of bottom intrusion (Nakano et al. 2004). The responses of heterotrophic bacteria to nutrient supply or temperature changes have been observed to be similar to that of picophytoplankton (Nakano et al. 2004). It is likely that bacterial growth rates in Uchiumi Bay are nearly saturated at ambient levels of nutrients and/or organic matter, and that bacterial abundance is subject to relatively weak bottom-up control. Although we did not find a significant relationship between temperature and bacterial abundance or growth rate, bacterial abundance was seasonally high during the thermally stratified period (Fig. 3, S. Nakano unpubl. data). Thus temperature is a possible regulating factor. Although we only evaluated glucose, other organic matter, other than glucose, probably regulates the bacterial abundance. The effect of temperature and other organic substrates should be further investigated to understand the bacterial dynamics of Uchiumi Bay.

Acknowledgements. We thank K. Hyodo, T. Hirose and the staff of Ainan Institute of Oceanic and Fishery Center, and the students of Ehime University, for their help in field monitoring. Thanks are also due to Professor Suzuki and other members of the Aquatic Biology and Ecology Laboratory of CMES, Ehime University, for their advice, discussions and encouragement throughout the study. We thank Dr. T. W. Miller for correction of our English and constructive comments on the manuscript. The present study was partly supported by the Grant-in-Aid for Scientific Research No. 16201004, JSPS, and the Research Fund of coastal environment in Uchiumi Bay, Ainan Town, Ehime Prefecture.

\section{LITERATURE CITED}

Alonso C, Pernthaler J (2006) Concentration-dependent patterns of leucine incorporation by coastal picoplankton. Appl Environ Microbiol 72:2141-2147

Alonso-Saez L, Gasol JM (2007) Seasonal variations in the contributions of different bacterial groups to the uptake of low-molecular-weight compounds in Northwestern Mediterranean coastal waters. Appl Environ Microbiol 73: $3528-3535$

Azam F, Fenchel T, Field JG, Gray JS, Meyer-Reil LA, Thingstad $F$ (1983) The ecological role of water-column microbes in the sea. Mar Ecol Prog Ser 10:257-263

Billen G, Servais P, Becquevort S (1990) Dynamics of bacterioplankton in oligotrophic and eutrophic aquatic environments: Bottom-up or top-down control? Hydrobiologia $207: 37-42$

Bird DF, Kalff J (1984) Empirical relationships between bacterial abundance and chlorophyll concentration in fresh and marine waters. Can J Fish Aquat Sci 41:1015-1023

Carlson CA, Giovannoni SJ, Hansell DA, Goldberg SJ and others (2002) Effect of nutrient amendments on bacterioplankton production, community structure, and DOC utilization in the northwestern Sargasso Sea. Aquat Microb Ecol 30:19-36

Caron DA, Lim EL, Sanders RW, Dennet MR, Berninger UG (2000) Responses of bacterioplankton and phytoplankton to organic carbon and inorganic nutrient additions in contrasting oceanic ecosystems. Aquat Microb Ecol 22:175-184

Cho BC, Azam F (1990) Biogeochemical significance of bacterial biomass in the ocean's euphotic zone. Mar Ecol Prog Ser 63:253-259

Choi KH, Dobbs FC, Cowen RK (2001) Short-term temporal and spatial dynamics of bacterioplankton near Barbados in the Caribbean Sea. Aquat Microb Ecol 25:43-53

Church MJ, Hutchins DA, Ducklow HW (2000) Limitation of bacterial growth by dissolved organic matter and iron in the Southern Ocean. Appl Environ Microbiol 66:455-466

Cole JJ, Findlay S, Pace ML (1988) Bacterial production in fresh and saltwater ecosystems: a cross-system overview. Mar Ecol Prog Ser 43:1-10

> Dufour PH, Torreton JP (1996) Bottom-up and top-down control of bacterioplankton from eutrophic to oligotrophic sites in the tropical northeastern Atlantic Ocean. DeepSea Res I 43:1305-1320

Elser JJ, Stabler LB, Hassett RP (1995) Nutrient limitation of bacterial growth and rates of bacterivory in lakes and oceans: a comparative study. Aquat Microb Ecol 9: 105-110

Felip M, Pace ML, Cole JJ (1996) Regulation of planktonic bacterial growth rates: the effects of temperature and resources. Microb Ecol 31:15-28

> Flaten GAF, Castberg T, Tanaka T, Thingstad TF (2003) Interpretation of nutrient-enrichment bioassays by looking at sub-populations in a marine bacterial community. Aquat Microb Ecol 33:11-18

Geller W, Berberovic R, Gaedke U, Muller H, Pauli HR, Tilzer MM, Weisse T (1991) Relationship among the components of autotrophic and heterotrophic plankton during the seasonal cycle 1987 in Lake Constance. Verh Int Verein Theor Angew Limnol 24:831-836

> Goldman JC, Dennett MR (1991) Ammonium regeneration and carbon utilization by marine bacteria grown on mixed substrates. Mar Biol 109:369-378

Hall EK, Neuhauser C, Cotner JB (2008) Toward a mechanistic understanding of how natural bacterial communities respond to changes in temperature in aquatic ecosystems. ISME J 2:471-481

> Hamels I, Muylaert K, Casteleyn G, Vyverman W (2001) Uncoupling of bacterial production and flagellate grazing in aquatic sediments: a case study from an intertidal flat. Aquat Microb Ecol 25:31-42

$>$ Hashimoto T, Nakano S (2003) Effect of nutrient limitation on abundance and growth of phytoplankton in a Japanese 
pearl farm. Mar Ecol Prog Ser 258:43-50

Hoch MP, Bronk DA (2007) Bacterioplankton nutrient metabolism in the Eastern Tropical North Pacific. J Exp Mar Biol Ecol 349:390-404

Ichinotsuka D, Ueno H, Nakano S (2006) The relative importance of nanoflagellates and ciliates as consumers of bacteria in a coastal sea area dominated by oligotrichous Strombidium and Strobilidium. Aquat Microb Ecol 42: 139-147

Jansson M, Blomqvist P, Jonsson A, Bergstroem AK (1996) Nutrient limitation of bacterioplankton, autotrophic and mixotrophic phytoplankton, and heterotrophic nanoflagellates in Lake Oertraesket. Limnol Oceanogr 41: 1552-1559

Kaneda A, Takeoka H, Koizumi Y (2002a) Periodic occurrence of diurnal signal of ADCP backscatter strength in Uchiumi Bay, Japan. Estuar Coast Shelf Sci 55:323-330

Kaneda A, Takeoka H, Nagata E, Koizumi Y (2002b) Periodic intrusion of cold water from the Pacific Ocean into the bottom layer of the Bungo Channel, Japan. J Oceanogr 58: $547-556$

Katano T, Hirose M, Nakano S (2004) Discrimination between two phycoerythrin-pigment types of Synechococcus and their seasonal succession in the Uwa Sea. Microbes Environ 19:7-12

Katano T, Kaneda A, Takeoka H, Nakano S (2005) Seasonal changes in abundance and composition of picophytoplankton in relation to occurrence of 'Kyucho' and bottom intrusion in Uchiumi Bay, Japan. Mar Ecol Prog Ser 298:59-67

Kawabata K, Nakanishi M (1996) Food web structure and biodiversity in lake ecosystems. In: Abe T, Levin S, Higashi M (eds) Biodiversity: an ecological perspective. Springer, New York, p 202-213

Kirchman D, Ducklow H, Mitchell R (1982) Estimates of bacterial growth from changes in uptake rates and biomass. Appl Environ Microbiol 44:1296-1307

Koizumi Y (1991) A process of water exchange in Shitaba Bay during the phenomenon of Kyucho. Bull Coast Oceanogr 29:82-90

Koizumi Y, Kohno Y (1994) An influence of the Kyucho on a mechanism of diatom growth in Sitaba Bay in summer. Engan Kaiyou Kenkyu Note 32:81-89

Koizumi Y, Nishikawa S, Yakushiji F, Uchida T (1997) Germination of resting stage cells and growth of vegetative cells in diatoms caused by Kyucho events. Suisan Kaiyou Kenkyu 61:275-287 (in Japanese with English abstract)

Lee CW, Kudo I, Yanada M, Maita Y (2001) Bacterial abundance and production and heterotrophic nanoflagellate abundance in subarctic coastal waters (Western North Pacific Ocean). Aquat Microb Ecol 23:263-271

Malmstrom RR, Cottrell MT, Elifantz J, Kirchman DL (2005) Biomass production and assimilation of dissolved organic matter by SAR11 bacteria in the Northwest Atlantic Ocean. Appl Environ Microbiol 71:2979-2986

Middelboe M, Nielsen TG, Bjornsen PK (2002) Viral and bacterial production in the North Water: in situ measurements, batch-culture experiments and characterization and distribution of a virus-host system. Deep-Sea Res II 49:5063-5079

Moran R, Porath D (1980) Chlorophyll determination in intact tissues using $N, N$-dimethylformamide. Plant Physiol 65: 478-479

Morris DP, Lewis WM Jr (1992) Nutrient limitation of bacterioplankton growth in Lake Dillon, Colorado. Limnol Oceanogr 37:1179-1192

Nagata T, Watanabe Y (1990) Carbon- and nitrogen-to-volume ratios of bacterioplankton grown under different nutritional conditions. Appl Environ Microbiol 56:1303-1309

> Nakano S, Tomaru Y, Katano T, Kaneda A and others (2004) The dynamics of microbial and herbivorous food webs in a coastal sea with special reference to intermittent nutrient supply from bottom intrusion. Aquat Ecol 38:485-493

Pace ML (1988) Bacterial mortality and the fate of bacterial production. Hydrobiologia 159:41-49

> Pace ML, Cole JJ (1994) Comparative and experimental approaches to top-down and bottom-up regulation of bacteria. Microb Ecol 28:181-193

Pinhassi J, Gomez-Consarnau L, Alonso-Saez L, Sala MM, Vidal M, Pedros-Alio C, Gasol JM (2006) Seasonal changes in bacterioplankton nutrient limitation and their effects on bacterial community composition in the NW Mediterranean Sea. Aquat Microb Ecol 44:241-252

Pomeroy LR, Deibel D (1986) Temperature regulation of bacterial activity during the spring bloom in Newfoundland coastal waters. Science 233:359-361

Porter KG, Feig YS (1980) The use of DAPI for identifying and counting aquatic microflora. Limnol Oceanogr 25:943-948

> Riemann L, Steward GF, Azam F (2000) Dynamics of bacterial community composition and activity during a mesocosm diatom bloom. Appl Environ Microbiol 66:578-587

Rivkin RB, Anderson MR (1997) Inorganic nutrient limitation of oceanic bacterioplankton. Limnol Oceanogr 42:730-740

Sala MM, Peters F, Gasol JM, Pedrós-Alió C, Marrasé C, Vaqué D (2002) Seasonal and spatial variations in the nutrient limitation of bacterioplankton growth in the northwestern Mediterranean. Aquat Microb Ecol 27:47-56

Schweitzer B, Simon M (1995) Growth limitation of planktonic bacteria in a large mesotrophic lake. Microb Ecol 30:89-104

Sherr EB, Sherr BF, Cowles TJ (2001) Mesoscale variability in bacterial activity in the Northeast Pacific Ocean off Oregon, USA. Aquat Microb Ecol 25:21-30

Simon M, Cho BC, Azam F (1992) Significance of bacterial biomass in lakes and the ocean: comparison to phytoplankton biomass and biogeochemical implications. Mar Ecol Prog Ser 86:103-110

- Sommaruga R, Robarts RD (1997) The significance of autotrophic and heterotrophic picoplankton in hypertrophic ecosystems. FEMS Microbiol Ecol 24:187-200

Takeoka H, Yoshimura T (1988) The Kyucho in Uwajima Bay. J Oceanogr 44:6-16

Takeoka H, Akiyama H, Kikuchi T (1993) The Kyucho in the Bungo Channel, Japan: periodic intrusion of oceanic warm water. J Oceanogr 49:369-382

Takeoka H, Koizumi Y, Kaneda A (2000) Year-to-year variation of a Kyucho and a bottom intrusion in the Bungo Channel, Japan. In: Yanagi $\mathrm{T}$ (ed) Interactions between estuaries, coastal seas and shelf seas. Terra Scientific Publishing, Tokyo, p 197-215

Tezuka Y (1990) Bacterial regeneration of ammonium and phosphate as affected by the carbon:nitrogen:phosphorus ratio of organic substrates. Microb Ecol 19:227-238

Tomaru Y, Udaka N, Kawabata Z, Nakano S (2002) Seasonal change of seston size distribution and phytoplankton composition in bivalve pearl oyster Pinctada fucata martensii culture farm. Hydrobiologia 481:181-185

> Vaqué D, Casamayor EO, Gasol JM (2001) Dynamics of whole community bacterial production and grazing losses in seawater incubations as related to the changes in the proportions of bacteria with different DNA content. Aquat Microb Ecol 25:163-177

White PA, Kalff J, Rasussen JB, Gasol JM (1991) The effect of temperature and algal biomass on bacterial production and specific growth rate in freshwater and marine habitats. Microb Ecol 21:99-118 